\title{
An outbreak of anthrax in endangered Rothschild's giraffes in Mwea National Reserve, Kenya
}

This article was published in the following Dove Press journal:

Veterinary Medicine: Research and Reports

12 November 2013

Number of times this article has been viewed

\author{
Titus Kaitho' \\ David Ndeereh' \\ Bernard Ngoru ${ }^{2}$ \\ 'Veterinary, Capture and Captive \\ Wildlife Management Department, \\ Wildlife Conservation Division, \\ Kenya Wildlife Service, Nairobi, \\ Kenya; ${ }^{2}$ Ecological Monitoring, \\ Bio-Prospecting and Biodiversity \\ Information Management Department, \\ Biodiversity Research and Monitoring \\ Division, Kenya Wildlife Service, \\ Nairobi, Kenya
}

\begin{abstract}
An anthrax outbreak occurred at the Mwea National Reserve between May 2011 and July 2011. This outbreak affected endangered Rothschild's giraffes (Giraffa camelopardalis ssp. rothschildi). Eleven giraffe carcasses were found during the 3-month period. One lesser kudu (Ammelaphus imberbis), the only one of its species in the national reserve, also succumbed to the illness. An investigation was carried out, and the presence of anthrax was rapidly confirmed using bacteriological methods. To stop the occurrence of more deaths of this endangered species, a total of 20 giraffes were vaccinated against anthrax and black quarter. The giraffe carcasses that were found were completely burned; this was done to decontaminate the environment. For a period of 2 years postvaccination, no anthrax-related mortalities in Rothschild's giraffes were reported at the Mwea National Reserve.
\end{abstract}

Keywords: anthrax outbreak, burning of carcasses, Rothschild's giraffes, vaccination

\section{Introduction}

Rothschild's giraffe (Giraffa camelopardalis ssp. rothschildi), is the latest African mammal to be classified as endangered by the International Union for the Conservation of Nature. The Rothschild's giraffe population is close to meeting the population threshold for critically endangered species under the International Union for the Conservation of Nature's Red List of Threatened Species. ${ }^{1}$

The total population of Rothschild's giraffes is about 670 in isolated populations in the wild. ${ }^{2}$ The main reason for the decline in the numbers of these giraffes has been identified as habitat loss. In Kenya, all known wild populations of the Rothschild's giraffe have been eradicated by agricultural development, and remaining populations are confined to national parks, private properties, and other protected areas. These remaining populations are physically isolated from one another, making it impossible for them to interbreed, and population growth is further hindered as a result of the closed nature of these conservation areas, which have reached or exceeded their carrying capacities. A major loss of this subspecies is also accounted for by diseases and poaching. An anthrax outbreak occurred at the Mwea National Reserve in Mbeere County, Kenya between May 2011 and July 2011. Although the prevalence of livestock anthrax is declining in many parts of the world - with an increasing number of countries that are probably truly free of the disease - anthrax is still a threat to wildlife populations in many national parks and in some game ranching areas. ${ }^{3}$
Correspondence: Titus Kaitho Wildlife Conservation Division, Kenya Wildlife Service, PO Box 4024I Code 100, Nairobi, Kenya

Tel +254728932369

Email titus@kws.go.ke submit your manuscript $\mid$ www.dovepress.com

Dovepress
Veterinary Medicine: Research and Reports 2013:4 45-48

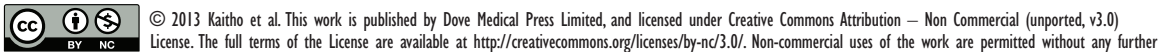
permission from Dove Medical Press Limited, provided the work is properly attributed. Permisisions beyond the scope of the License are administered by Dove Medical Press limited. Information on how to request permisision may be found at http://www.dovepress.com/permissions.php 


\section{Materials and methods}

In 2011, an anthrax outbreak occurred at the Mwea National Reserve in Mbeere County, Kenya, which is located between latitude $0045^{\prime} \mathrm{N}$ and $0052^{\prime} \mathrm{N}$, and longitude $37035^{\prime} \mathrm{E}$ and $37040^{\prime} \mathrm{E}$. The reserve is $48 \mathrm{~km}^{2}$ and is situated between the confluence of the Thiba River and the Tana Rivers, which are characterized by a beautiful scenery and long river frontage. The reserve is completely fenced, with electric wires running along the two rivers forming a natural barrier on the eastern and southern boundaries. The mean annual rainfall in the reserve is between $510-760 \mathrm{~mm}$, with two peak rainfall seasons falling between March-May and October-December. The mean minimum and maximum temperatures are $14^{\circ} \mathrm{C}$ and $30^{\circ} \mathrm{C}$, respectively. The reserve is endowed with relatively low animal species diversity and abundance. The most common species in the reserve are African elephants, African buffaloes, Olive baboons, Vervet monkeys, Sykes' monkeys, warthogs, plains zebras, Rothschild's giraffes, common impalas, elands, waterbucks, duikers, dik-diks, crocodiles, hippopotami, and lesser kudus. ${ }^{4}$

Between May 2011 and July 2011, a survey conducted by veterinary professionals and a team of biologists found eleven carcasses of Rothschild's giraffes and one lesser kudu
(Ammelaphus imberbis). Anthrax was rapidly confirmed using bacteriological methods. We decontaminated the environment by rapid incineration of all of the carcasses in one day. Carcasses were burned to ash using plenty of deadwood. This exercise was carried out after a clear briefing; instructions were provided, and this procedure was carried out under strict supervision by reserve management and the veterinary team. All of the people involved were given clear instructions to not touch the carcasses with their bare hands, and the members of the team were provided with gloves and face masks. Figure 1 shows the sites where the Rothschild's giraffes and the lesser kudu carcasses were found.

The veterinary team vaccinated the remaining giraffes with the Blanthax ${ }^{\circledR}$ vaccine (Cooper K- Brands Ltd, Nairobi, Kenya), which is a black quarter and anthrax vaccine (a Clostridium chauvoei and living avirulent anthrax spore vaccine). The vaccine was delivered remotely using $3 \mathrm{~mL}$ darts delivered by a Dan-Inject ${ }^{\circledR}$ dart rifle (Dan-Inject APS, Sellerup Skowej, Denmark). In addition, $2 \mathrm{~mL}$ $(12.5 \% \mathrm{v} / \mathrm{v})$ of $\mathrm{Cl}$. chauvoei anaculture and $2 \times 10^{6}$ spores of Bacillus anthracis were administered through a dart with small needles (size: $2.0 \times 40 \mathrm{~mm}$ or $1.5 \times 30 \mathrm{~mm}$ ) intended to deposit the vaccine subcutaneously.

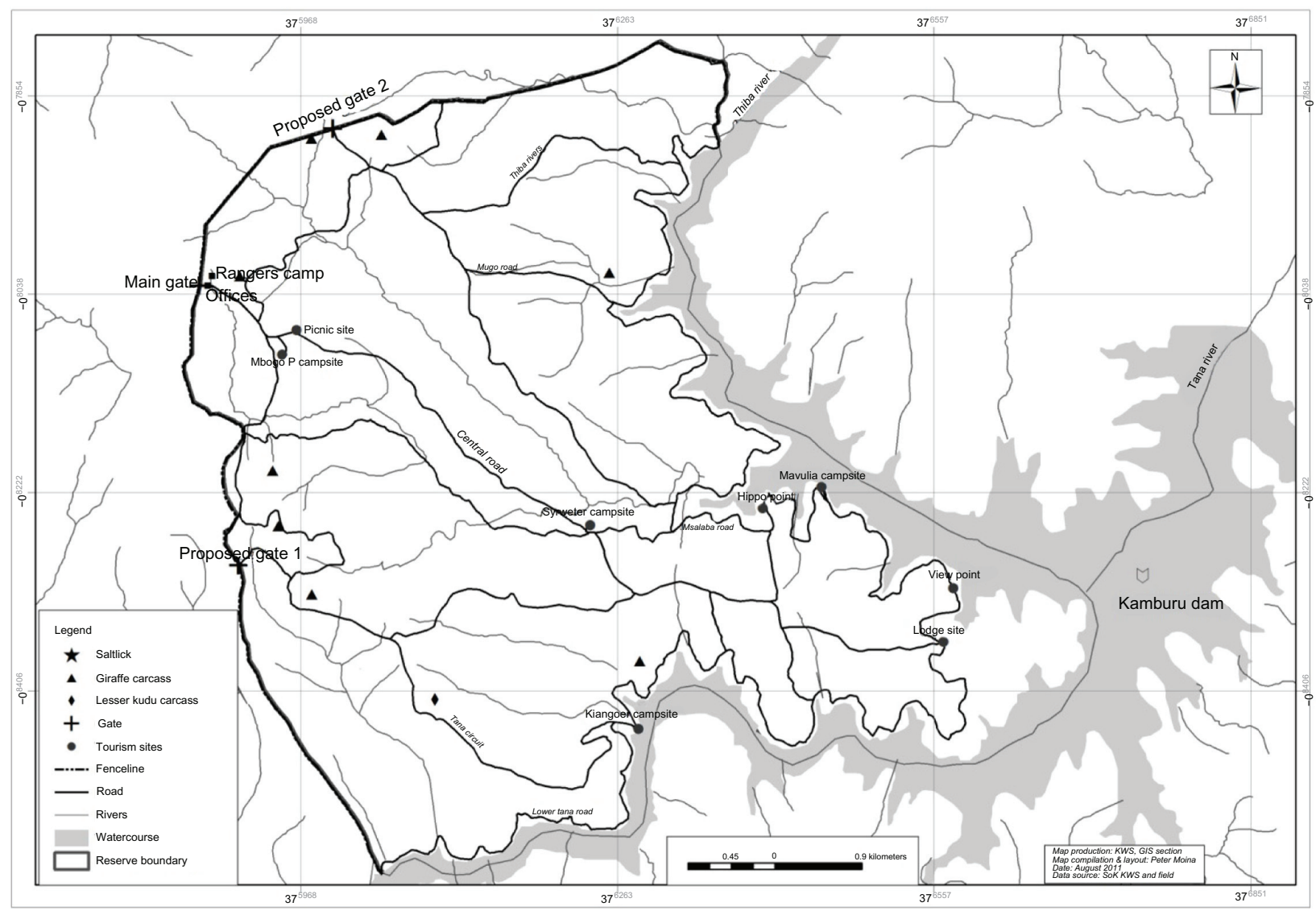

Figure I Locations of Rothschild's giraffes and the lesser kudu carcasses found at the Mwea National Reserve, Mbeere County, Kenya. 


\section{Results}

Before the anthrax outbreak, there were an estimated 44 Rothschild's giraffes at the Mwea National reserve. ${ }^{4}$ Eleven giraffes died during the outbreak. We vaccinated 20 of 33 giraffes that were sighted from five herds; this represented $60.6 \%$ coverage of the population which, in our opinion, was satisfactory. The remaining giraffes were not vaccinated because they disappeared into difficult terrains and dense bushes where they could not be pursued. In addition, when the herds were resighted, the darts had already fallen off, making it difficult to identify the animals that were previously darted. Although not all giraffes were vaccinated, the number of those that were vaccinated was sufficient to halt the outbreak.

\section{Discussion}

To our knowledge, we are reporting the first outbreak of anthrax in Rothschild's giraffes at the Mwea National Reserve. Although anthrax infects a wide range of species, outbreaks are typically associated with only a few species. ${ }^{5}$ During December 2005 and March 2006, an anthrax outbreak in Samburu, Kenya occurred in equids, affecting endangered Grevy's zebras, plains zebras, and donkeys. ${ }^{6}$ In contrast, the 2011 Mwea National Reserve anthrax outbreak affected only endangered Rothschild's giraffes and one lesser kudu, despite the presence and abundance of other susceptible species in the reserve. ${ }^{4}$ Experts agree that thorough burning of the carcasses is the preferred method of disposal because spores are destroyed. Carcass burial sites frequently remain reservoirs of anthrax for many years. ${ }^{3}$ The burning of carcasses and vaccination of the affected species in this particular outbreak apparently halted the spread of infection and mortalities due to anthrax. However, it has been reported that the burning of carcasses of diseased impalas in 1984 at the Lake Manyara National Park in Tanzania had no apparent effect on anthraxrelated mortality. ${ }^{7}$

It was important to respond quickly to eliminate the carcasses by immediate incineration, since spores are rapidly formed and spread by flies and scavengers, especially vultures, that may transmit anthrax over long distances., ${ }^{3,8}$ The management team at the reserve was advised to adequately cover all the carcasses (taking all necessary hygiene precautions) with bushes to deny access to the sites by other animals because anthrax was considered a differential diagnosis prior to laboratory confirmation. Anthrax vaccination of Rothschild's giraffes that were living in the wild has not been attempted; however, vaccinations of rare, endangered species (including rhinoceros and roan antelopes) have been attempted from a helicopter using dropout darts during the 2004 Malilangwe anthrax outbreak. ${ }^{9}$ In the Mwea National Reserve ecosystem, anthrax outbreaks were reported in humans and hippopotami in $2009 .{ }^{10}$ In the 2009 anthrax outbreak, three people died and more than 100 people developed lesions after becoming infected with anthrax after they consumed meat from dead hippopotami. The spores from the 2009 outbreak could have been the original source of the 2011 outbreak that occurred among the Rothschild's giraffes. Anthrax has remained enzootic in the Mwea National Reserve ecosystem; it has also been endemic throughout Kenya (J Dudley, International Society for Infectious Diseases, email communication, 2006 Available from: http://www.controlofbiohazards.com/ Documents/AnthraxJan2006--Dec2006.pdf). ${ }^{11}$ The 2011 outbreak occurred immediately after the March-April long rain season when there was abundant grass and browse. This is the same period during which ambient temperatures and humidity are at their highest. In 1997, the occurrence of anthrax exploded in an Australian summer. ${ }^{12}$ The weather conditions in north-central Victoria, Australia (the area where the 1997 outbreak occurred) were characterized by a long dry spell and periods of high daily and nightly temperatures, continuously high humidity during that period, and higher than normal temperatures.

Once this 2011 anthrax outbreak was confirmed, we notified the veterinary department; consequently, quarantine was imposed with prohibition of movement of the livestock into and outside of the county, and people (including tourists/visitors) were prohibited from entering the reserve. We rapidly disposed of the carcasses by burning all of them in one day. We also alerted the local health authorities and alerted local communities. The veterinary department vaccinated livestock in the county. The standard control of anthrax involves breaking the cycle of infection, which can be achieved through correct disposal of anthrax carcasses, correct disinfection and decontamination, disposal of contaminated materials, and vaccination of susceptible animals that had been exposed. ${ }^{12,13}$

Immunization due to prior epidemics can provide greater community protection than the random vaccination of networks that exhibit heterogeneous contact patterns; the reverse is true for highly structured populations (which have low contact networks in terms of space, time, sex, age, species difference, genetic diversity among other factors).${ }^{14}$ Immunization via vaccination differs from natural immunization in an important way: epidemics preferentially infect (and subsequently immunize) highly connected individuals and contiguous clusters of individuals. Rothschild's giraffe herds in this reserve resemble highly connected 
individuals, and they represent contiguous clusters of individuals due to the presence of natural barriers (rivers), the electrical fence, and given that they exist within a small area (they are located within an area of the reserve that is $48 \mathrm{~km}^{2}$ in size).

Earlier work has shed some light on the ecological drivers of anthrax infection, and it has been suggested that soil alkalinity and prolonged droughts or rain are useful predictors of disease occurrence that could guide risk-based surveillance. ${ }^{5}$ We believe that anthrax spores still persist in this ecosystem, especially in the soil and vegetation. To mitigate the losses due to anthrax mortalities, we recommend continuous disease surveillance and the timely reporting of any mortality in all species in this reserve. Our prompt and timely intervention, that consisted of breaking the cycle of infection and vaccinating susceptible Rothschild's giraffes, halted this outbreak.

\section{Acknowledgments}

Kenya Wildlife Service - Veterinary, Capture \& Captive Wildlife Management Department staff, Peter Maina and Peter Hongo of Geographic Information Systems Section and Mwea National Reserve Management, thank you for cooperation and facilitation.

\section{Disclosure}

The authors report no conflicts of interest in this work.

\section{References}

1. Fennessy, J. \& Brenneman, R. 2010. Giraffa camelopardalis ssp. rothschildi. IUCN 2013. IUCN Red List of Threatened Species. Version 2013.1. Available from: www.iucnredlist.org. Accessed September 25, 2013.
2. Giraffe Conservation Foundation [webpage on the Internet]. Giraffe indaba - a world first held in Namibia. Giraffa Newsletter. 2011;5(1): 2-3. Available from: http://giraffeconservation.org/download_newsletter.php?id=7. Accessed March 15, 2012.

3. Hugh-Jones ME, de Vos V. Anthrax and wildlife. Rev Sci Tech. 2002;21(2):359-383.

4. Ngoru B. Proposed re-stocking of Mwea National Reserve. Mountain Conservation Area Proposal. Kenya Wildlife Service Report; 2010:10-11.

5. Hampson K, Lembo T, Bessell P, et al. Predictability of anthrax infection in the Serengeti, Tanzania. J Appl Ecol. 2011;48(6):1333-1344.

6. Muoria PK, Muruthi P, Kariuki WK, Hassan BA, Mijele D, Oguge NO. Anthrax outbreak among Grevy's zebras (Equus grevyi) in Samburu, Kenya. Afr J Ecol. 2007;45(4):483-489.

7. Prins HHT, Weyerhaeuser EJ. Epidemics in populations of wild ruminants: anthrax and impala, rinderpest and buffalo in Lake Manyara National Park, Tanzania. Oikos. 1987;49(1):28-38.

8. Turnbull PC, Diekmann M, Kilian JW, et al. Naturally acquired antibodies to Bacillus anthracis protective antigen in vultures of southern Africa. Onderstepoort J Vet Res. 2008;75(2):95-102.

9. Clegg SB, Turnbull PC, Foggin CM, Lindeque PM. Massive outbreak of anthrax in wildlife in the Malilangwe Wildlife Reserve, Zimbabwe. Vet Rec. 2007;160(4):113-118.

10. Chege S, Kariuki J. Disease investigation at Mwea National Reserve report. Case Investigation. Kenya Wildlife Service Report. 2009:2-3.

11. Republic of Kenya Zoonotic Disease Unit. Quarterly Bulletin: The East Africa Public Health Lab Network Newsletter. Nairobi, Kenya: Republic of Kenya Zoonotic Disease Unit; 2012. Available from: http://zdukenya.org/wp-content/uploads/2013/02/Bulletin-Alarm-overZoonotic-Diseases.pdf. Accessed August 16, 2013.

12. Turner AJ, Galvin JW, Rubira RJ, Miller GT. Anthrax explodes in an Australian summer. J Appl Microbiol. 1999;87(2):196-199.

13. Turner AJ, Galvin JW, Rubira RJ, Condron RJ, Bradley T. Experiences with vaccination and epidemiological investigations on an anthrax outbreak in Australia in 1997. J Appl Microbiol. 1999;87(2): 294-297.

14. Ferrari MJ, Bansal S, Meyers LA, Bjørnstad ON. Network frailty and the geometry of herd immunity. Proc Biol Sci. 2006;273(1602): $2743-2748$.
Veterinary Medicine: Research and Reports

\section{Publish your work in this journal}

Veterinary Medicine: Research and Reports is an international, peer-reviewed, open access journal publishing original research, case reports, editorials, reviews and commentaries on all areas of veterinary medicine. The manuscript management system is completely online and includes a very quick and fair peer-review system.

\section{Dovepress}

Visit http://www.dovepress.com/testimonials.php to read real quotes from published authors. 